\title{
PENINGKATAN MOTIVASI BELAJAR BAHASA INGGRIS MATERI CAPTION MENGGUNAKAN MEDIA INSTAGRAM SISWA KELAS XII IPA 4 SMA NEGERI 1 DAWARBLANDONG MOJOKERTO TAHUN PELAJARAN 2020/2021
}

\author{
YKE ROSMANAH \\ SMAN 1 Dawarblandong - Kab. Mojokerto \\ Email : ykerosmanah@sman1dawarblandong.org
}

\begin{abstract}
ABSTRAK
Tujuan penelitian ini adalah untuk mengetahui peningkatan motivasi dan hasil belajar siswa setelah dilakukan pembelajaran menggunakan Instagram. Penelitian ini menggunakan subyek siswa kelas XII IPA 4 SMA Negeri 1 Dawarblandong, Kab. Mojokerto Tahun Pelajaran 2020/2021 dan obyek dalam penelitian ini adalah motivasi dan hasil belajar siswa. Penelitian ini merupakan penelitian tindakan kelas yang terdiri atas 2 (dua) siklus yang setiap siklus terdiri atas 4 (empat) tahapan. Siklus I dan II masing-masing terdiri dari 3 kali pertemuan. Metode pengumpulan data yang digunakan adalah tes dan observasi. Teknik analisis data yang dipakai adalah teknik analisis deskriptif kualitatif. Pada siklus pertama didapatkan hasil rata - rata motivasi belajar siswa baru mencapai $67 \%$, sedangkan hasil belajar siswa baru $74 \%$ siswa yang tuntas belajar. Pada siklus kedua hasil rata - rata motivasi belajar siswa meningkat hingga $82 \%$, sedangkan hasil belajar siswa $100 \%$ telah mencapai $\geq 67$. Dengan demikian penggunaan Instagram dalam materi Caption pada pembelajaran Bahasa Inggris bisa meningkatkan motivasi belajar siswa kelas XII IPA 4 SMAN 1 Dawarblandong tahun pelajaran 2020/2021
\end{abstract}

Kata Kunci: Instagram, Motivasi belajar, materi Caption

\section{PENDAHULUAN}

Hantaman wabah virus Corona (Covid-19) di dunia, khususnya di Indonesia telah merubah tatanan kehidupan di segala bidang. Pembelajaran tatap muka dikhawatirkan akan menambah penyebaran Covid-19. Di sisi lain, pendidikan tetap harus berjalan, siswa tetap harus mendapatkan pembelajaran karena jika tidak, maka masa depan siswa khususnya dan masa depan bangsa Indonesia secara umum akan hancur. Oleh karenanya diperlukan suatu metode pembelajaran baru untuk menyiasatinya.

Pendidikan Jarak Jauh yang selanjutnya disebut PJJ adalah pendidikan yang peserta didiknya terpisah dari pendidik dan pembelajarannya menggunakan berbagai sumber belajar melalui penerapan prinsip-prinsip teknologi pendidikan/pembelajaran. Pembelajaran Jarak Jauh adalah salah satu cara yang memungkinkan untuk dilaksanakan dalam masa pandemi Covid-19 ini.

Kenyataannya penerapan PJJ tidaklah mudah. Banyak kendala terjadi, mulai dari hal teknis misalnya jaringan internet yang terbatas dan ketersediaan paket data, maupun hal berkenaan dengan proses belajar mengajar. Dalam proses belajar mengajar, guru mendapatkan tantangan yang sangat berat, karena motivasi belajar siswa menurun dan otomatis prestasi belajar siswa pun menurun. Hal ini terjadi karena beberapa faktor, siswa mengalami kejenuhan dengan model PJJ berbasis online yang begitu-begitu saja, penyajian materi pelajaran tidak menarik dan lain-lain. Untuk itu, guru hendaknya mengembangkan strategi belajar mengajar yang bisa meningkatkan motivasi belajar siswa dalam masa pandemi Covid-19 ini.

Diperlukan solusi untuk menyelesaikan masalah tersebut. Salah satu caranya yaitu pembelajaran menggunakan media pembelajaran audio visual seperti yang dinyatakan oleh Purwono bahwa pembelajaran akan meningkat bila menggunakan pembelajaran berbasis audio visual (Purwono, Yutmini, \& Anitah, 2014). Dalam pelajaran Bahasa Inggris kelas XII materi Caption, dibutuhkan ketrampilan siswa dalam memberikan Caption (teks penyerta) 
terhadap suatu gambar. Maka penggunaan Instagram sebagai media pembelajaran materi Caption sangat tepat, seperti dinyatakan oleh Mei bahwa penggunaan media visual seperti gambar, animasi dan video dapat digunakan sebagai media pembelajaran yang baik (Mei dkk, 2019).

Di SMAN 1 Dawarblandong, motivasi dan prestasi belajar siswa dalam pelajaran Bahasa Inggris utamanya materi Caption kelas XII melalui PJJ berbasis online menurun. Pembelajaran Jarak Jauh yang dilaksanakan di SMAN 1 Dawarblandong dilaksanakan secara online, menggunakan aplikasi Google Classroom. Siswa cenderung nampak bosan dengan pembelajaran cara tersebut, sehingga motivasi belajar siswa menurun. Berdasarkan kondisi tersebut, penulis berasumsi bahwa motivasi dan prestasi belajar siswa dalam pelajaran Bahasa Inggris bisa ditingkatkan dengan menggunakan Instagram sebagai sarana pembelajaran . Menurut Sardiman (2018), motivasi dapat dikatakan sebagai daya penggerak dari dalam dan di dalam subjek untuk melakukan aktivitas-aktivitas tertentu demi mencapai suatu tujuan.

Dalam proses belajar mengajar, guru mendapatkan tantangan yang sangat berat, karena motivasi belajar siswa menurun dan otomatis prestasi belajar siswa pun menurun. Hal ini terjadi karena beberapa faktor, siswa mengalami kejenuhan dengan model PJJ berbasis online yang begitu-begitu saja, penyajian materi pelajaran tidak menarik dan lain-lain. Untuk itu, guru hendaknya mengembangkan strategi belajar mengajar yang bisa meningkatkan motivasi belajar siswa dalam masa pandemi Covid-19 ini. Dalam kegiatan belajar, motivasi sangat diperlukan untuk membangkitkan gairah belajar siswa sehingga kegiatan belajar dapat berjalan dengan baik. Motivasi yang muncul dari diri siswa adalah keseluruhan daya penggerak didalam diri siswa yang memunculkan hasrat untuk belajar, hal ini menjamin kelangsungan dari kegiatan belajar dan memberikan arah pada kegiatan belajar, sehingga tujuan yang dikehendaki dapat tercapai, seperti yang dinyatakan oleh Sardiman (2018).

Dalam kegiatan belajar, siswa memerlukan motivasi. Motivasi yang ada pada pada diri setiap siswa itu memiliki ciri-ciri yang berbeda. Menurut Sardiman (2018), ciri-ciri motivasi yang ada pada siswa diantaranya adalah tekun menghadapi tugas, ulet menghadapi kesulitan, menunjukkan minat terhadap macam-macam masalah, lebih senang bekerja mandiri, artinya tanpa harus disuruh pun, ia akan mengerjakan apa yang menjadi tugasnya, dapat mempertahankan pendapatnya (kalau sudah yakin akan sesuatu), tidak mudah melepaskan hal yang diyakininya, artinya ia percaya dengan apa yangdikerjakannya dan senang mencari dan memecahkan masalah soal-soal.

Apabila siswa memiliki ciri-ciri motivasi belajar tersebut, maka itu artinya siswa memiliki motivasi yang cukup kuat untuk belajar. Untuk memunculkan motivasi belajar siswa diperlukan beberapa unsur yang mendukungnya, hal ini sesuai dengan pernyataan Uno (2017:23) bahwa motivasi belajar merupakan dorongan internal dan eksternal pada siswasiswa yang sedang belajar untuk mengadakan perubahan tingkah laku, pada umumnya dengan beberapa indikator atau unsur yang mendukung.

Instagram bisa menjadi salah satu pilihan media baru yang mendukung memunculkan motivasi belajar siswa. Disamping Instagram merupakan aplikasi favorit dan sudah ter-install di masing-masing ponsel siswa, Instagram juga berpotensi meningkatkan hasil dan motivasi belajar siswa, seperti yang tersebut dalam hasil penelitian Nugroho \& Ruwanto (2017), yang menyatakan bahwa media Instagram mampu memicu motivasi dan prestasi belajar siswa. Hal ini dikarenakan Instagram dapat diisi konten berupa ilustrasi gambar yang memudahkan materi untuk dipahami, meningkatkan rasa ingin tahu dan meningkatkan ketertarikan belajar mandiri siswa. Dalam hasil penelitian Jatmiko (2016), dinyatakan bahwa pembelajaran berbantuan aplikasi Instagram mampu meningkatkan motivasi siswa. Hal ini dikarenakan perhatian siswa meningkat karena mereka bisa belajar dengan menggunakan aplikasi yang selama ini mereka gunakan bukan untuk belajar dan itu menarik, serta siswa mengalami proses pengalaman belajar melalui metode yang baru.

Dalam pelajaran Bahasa Inggris kelas XII materi Caption, dibutuhkan ketrampilan siswa dalam memberikan Caption (teks penyerta) terhadap suatu gambar.Maka penggunaan 
Instagram sebagai media pembelajaran materi Caption sangat tepat. Pada instansi pendidikan SMAN 1 Dawarblandong, motivasi dan prestasi belajar siswa dalam pelajaran Bahasa Inggris utamanya materi Caption kelas XII melalui PJJ berbasis online menurun. Pembelajaran Jarak Jauh yang dilaksanakan di SMAN 1 Dawarblandong dilaksanakan secara online, menggunakan aplikasi Google Classroom. Siswa cenderung nampak bosan dengan pembelajaran cara tersebut, sehingga motivasi belajar siswa menurun. Berdasarkan kondisi tersebut, penulis berasumsi bahwa motivasi dan prestasi belajar siswa dalam pelajaran Bahasa Inggris bisa ditingkatkan dengan menggunakan Instagram sebagai sarana pembelajaran.

\section{METODE PENELITIAN}

Penelitian ini merupakan penelitian tindakan kelas, karena menggunakan strategi, metode, teknik atau model pembelajaran yang lebih efektif dan efisien. Penelitian ini menggunakan subyek siswa kelas XII IPA 4 SMA Negeri 1 Dawarblandong, Kab. Mojokerto Tahun Pelajaran 2020/2021 dan Obyek dalam penelitian ini adalah motivasi dan hasil belajar siswa. Metode pengumpulan data yang digunakan adalah tes dan observasi. Data penelitian ini dikumpulkan dari berbagai sumber yang meliputi Hasil pengamatan oleh peneliti yang dicatat dalam

Lembar observasi, hasil wawancara dengan siswa dan hasil tes mata pelajaran Bahasa Inggris siswa kelas XII IPA 4 SMA Negeri 1 Dawarblandong, Kab. Mojokerto sebelum pelaksanaan tindakan PTK. Berikut siklus penelitian yang peneliti gunakan sebagai dasar.

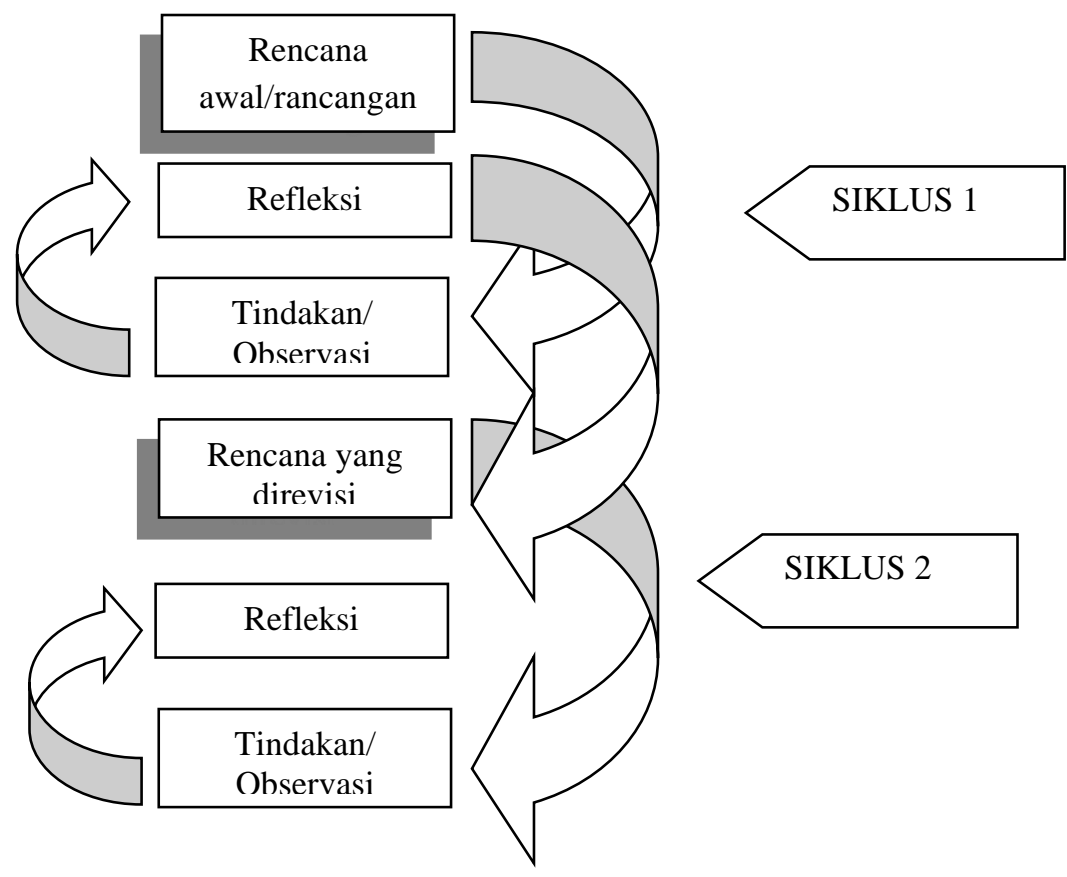

Gambar 1. Siklus Penelitian Tindakan Kelas

Adapun langkah - langkah dalam penelitian ini adalah :

1. Perencanaan, Adapun langkah - langkah perencanaan adalah identifikasi masalah, identifikasi siswa dan perencanaan solusi masalah.

2. Pelaksanaan Tindakan dimana tindakan dilaksanakan berdasar perencanaan namun tidak mutlak, oleh karenanya rencana tindakan harus bersufat fleksibel.

3. Observasi dan monitoring berfungsi untuk mendokumentasikan tindakan terkait. Observasi bersifat responsif, fleksibel dan terbuka untuk mencacat hal - hal yang tak terdugayang luput dalam katagori observasi yangada.

4. Refleksi dalam PTK adalah upaya untuk mengkaji yang telah dan belum terjadi, apa yang dihasilkan, kenapa hal itu bisa terjadi dan apa yang harus dilakukanselanjutnya. 
5. Evaluasi adalah proses untuk menentukan nilai belajar dan pembelajaran yang dilaksanakan . Evaluasi diarahkan pada penemuan bukti - bukti untuk menyusun jawaban terhdap tujuan penelitian.

6. Penyimpulan merupakan pengambilan intisari sajian data yang telah terorganisir dalam pernyataan singkat, padat danbermakna.

Teknik analisis data yang dipakai adalah teknik analisis deskriptif kualitatif. Analisis data yang digunakan dalam penelitian adalah yang dikemukakan oleh Miles dan Huberman dalam Kunandar yang terdiri dari tiga komponen yaitu:

1. Reduksi Data adalah langkah dalam proses analisis yaitu proses seleksi, pemfokusan, penyederhanaan dan abstraksi data.

2. Penyajian Data dimana data diolah kembali dan disajikan dalam bentuk matrik, gambar, skema, tabel sesuai dengan kondisi data.

3. Penarikan Kesimpulan dan Verifikasi. Dalam tahap ini peneliti mengambil kesimpulan penelitian dengan menjawab permasalahan yang diajukan dengan data dan bukti empiris yang telah terkumpul. Setelah dibuat kesimpulan, data perlu diverifikasi agar hasil penelitian mantap dan bisa dipertanggungjawabkan.

Indikator pencapaian belajar dengan meningkatnya motivasi belajar siswa rata - rata hingga $80 \%$ dalam hal yaitu ketekunan siswa menghadapi tugas, keuletan siswa menghadapi kesulitan, minat siswa terhadap bermacam-macam masalah, keinginan siswa bekerjasama, dan kemampuan siswa mempertahankan pendapatnya. Dengan menggunakan media Instagram dapat meningkatkan motivasi belajar siswa yang ditandai dengan siswa memperoleh nilai/ hasil belajar minimal 67 dan secara klasikal 95\% siswa harus mencapai batas minimal tersebut.

\section{HASIL DAN PEMBAHASAN}

\section{A. Siklus 1}

Proses pembelajaran diawali dengan siswa menggunakan lembar kerja siswa 1 yang diunggah dalam laman Instagram. Kegiatan pembelajaran dalam jaringan (daring) atau online kurang berjalan lancar seperti yang diharapkan, efektivitas penggunaan software belum nampak kuat. Namun secara garis besar hasil dari pengamatan, peserta pada siklus ini menunjukkan tanda-tanda positif pada siswa.

Guru tidak sepenuhnya mendominasi pembelajaran hanya menjelaskan sebelum proses belajar mengajar. Secara umum siswa mentaati aturan dalam pembelajaran ini dengan bertanya kepada teman atau guru, juga bisa mencari informasi dari segala sumber.

Dalam penelitian ini indikator motivasi belajar siswa dikembangkan dari pendapat Sardiman (2018) tentang ciri-ciri motivasi siswa. Rata-rata motivasi belajar pada siklus I baru mencapai $67 \%$ dengan perincian bahwa motivasi siswa tekun menghadapi tugas sebesar $72 \%$, Motivasi siswa ulet menghadapi kesulitan sebesar 62\%, Motivasi siswa menunjukkan minat terhadap macam-macam masalah sebesar $70 \%$, motivasi siswa lebih senang bekerja mandiri sebesar $80 \%$, motivasi siswa tidak cepat bosan pada tugas-tugas sebesar $70 \%$, kemampuan siswa mempertahankan pendapatnya sebesar 50\%, motivasi siswa tidak mudah melepaskan hal yang diyakininya sebesar $67 \%$, dan motivasi siswa senang mencari dan memecahkan masalah/soal-soal sebesar $67 \%$, seperti nampak dalam tabel 1 berikut ini:

Tabel 1. Motivasi Belajar Siswa

\begin{tabular}{|l|l|c|}
\hline NO & \multicolumn{1}{|c|}{ URAIAN } & PROSENTASE \\
\hline 1 & Tekun menghadapi tugas & $72 \%$ \\
\hline 2 & Ulet menghadapi kesulitan & $62 \%$ \\
\hline 3 & $\begin{array}{l}\text { Menunjukkan minat terhadap macam-macam } \\
\text { masalah }\end{array}$ & $70 \%$ \\
\hline
\end{tabular}




\begin{tabular}{|l|l|c|}
\hline 4 & Lebih senang bekerja mandiri & $80 \%$ \\
\hline 5 & Tidak cepat bosan pada tugas-tugas & $70 \%$ \\
\hline 6 & Dapat mempertahankan pendapatnya & $50 \%$ \\
\hline 7 & Tidak mudah melepaskan hal yang diyakininya & $65 \%$ \\
\hline 8 & $\begin{array}{l}\text { Senang mencari dan memecahkan } \\
\text { masalah/soal-soal. }\end{array}$ & $67 \%$ \\
\hline & Jumlah & $536 \%$ \\
\hline
\end{tabular}

Presentase perolehan nilai hasil belajar siswa tidak ada yang mendapat predikat $\mathrm{A} /$ sangat baik, yang mendapat predikat $\mathrm{B} /$ baik hanya $0.06 \%$, predikat $\mathrm{C} /$ cukup sebanyak $0.70 \%$ siswa dan yang mendapat predikat D/ kurang sebanyak $0.24 \%$,sesuai dengan Interval predikat berdasarkan KKM mata pelajaran Bahasa Inggris kelas XII SMAN 1 Dawarblandong yaitu 67 seperti nampak dalam tabel 2 berikut ini:

Tabel 2.Interval Predikat Berdasarkan KKM

\begin{tabular}{|c|c|c|c|c|}
\hline Rentang Nilai & Predikat & Kualifikasi & $\begin{array}{c}\text { Jumlah } \\
\text { siswa }\end{array}$ & Persentase \\
\hline $89-100$ & A & Sangat Baik & 0 & $0 \%$ \\
\hline $78-88$ & B & Baik & 2 & $0.06 \%$ \\
\hline $67-77$ & C & Cukup & 23 & $0.70 \%$ \\
\hline$<67$ & D & Kurang & 8 & $0.24 \%$ \\
\hline
\end{tabular}

Sedangkan pencapaian nilai hasil belajar siswa tertinggi adalah 80 dan nilai terendah adalah 60 dengan nilai rata-rata 69. Siswa yang mencapai nilai ketuntasan diatas KKM sebanyak $74 \%$ dan $26 \%$ belum tuntas seperti nampak pada tabel 3 , distribusi nilai hasil belajar siswa pada siklus 1 , berikut ini:

Tabel 3. Distribusi Nilai Hasil Belajar peserta didik Pada Siklus 1
\begin{tabular}{|c|l|c|}
\hline No. & \multicolumn{1}{|c|}{ Uraian } & Hasil Siklus \\
& & 1 \\
\hline 1. & Nilai Tertinggi & 80 \\
2. & Nilai Terendah & 60 \\
3. & Nilai rata-rata tes hasil belajar & 69 \\
4. & Jumlah peserta didik yang tuntas belajar & 25 \\
5. & Jumlah peserta didik yang tidak tuntas & 8 \\
6. & Persentase ketuntasan belajar & $74 \%$ \\
\hline
\end{tabular}

\section{B. Siklus 2}

Tampak peningkatan pemahaman siswa ini menunjukkan siswa tertarik dan senang mempelajari suatu konsep bila didukung suatu aplikasi lebih mudah dan cepat memahaminya.

Rata - rata motivasi belajar pada siklus I baru mencapai $82 \%$ dengan perincian bahwa motivasi siswa tekun menghadapi tugas sebesar 83\%, Motivasi siswa ulet menghadapi kesulitan sebesar $84 \%$, Motivasi siswa menunjukkan minat terhadap macam-macam masalah sebesar $87 \%$, motivasi siswa lebih senang bekerja mandiri sebesar $82 \%$, motivasi siswa tidak cepat bosan pada tugas-tugas sebesar $78 \%$, kemampuan siswa mempertahankan pendapatnya sebesar $80 \%$, motivasi siswa tidak mudah melepaskan hal yang diyakininya sebesar $80 \%$, dan motivasi siswa senang mencari dan memecahkan masalah/soal-soal sebesar $82 \%$, seperti nampak dalam tabel 4 berikut ini: 
Tabel 4 Motivasi Belajar Siswa

\begin{tabular}{|l|l|c|}
\hline NO & \multicolumn{1}{|c|}{ URAIAN } & PROSENTASE \\
\hline 1 & Tekun menghadapi tugas & $83 \%$ \\
\hline 2 & Ulet menghadapi kesulitan & $84 \%$ \\
\hline 3 & $\begin{array}{l}\text { Menunjukkan minat terhadap macam-macam } \\
\text { masalah }\end{array}$ & $87 \%$ \\
\hline 4 & Lebih senang bekerja mandiri & $78 \%$ \\
\hline 5 & Tidak cepat bosan pada tugas-tugas & $80 \%$ \\
\hline 6 & Dapat mempertahankan pendapatnya & $80 \%$ \\
\hline 7 & Tidak mudah melepaskan hal yang diyakininya \\
\hline 8 & $\begin{array}{l}\text { Senang mencari dan memecahkan } \\
\text { masalah/soal-soal. }\end{array}$ & $82 \%$ \\
\hline & $\begin{array}{l}\text { Jumlah Rata-rata } \\
\text { n }\end{array}$ \\
\cline { 2 - 2 }
\end{tabular}

Presentase perolehan nilai hasil belajar siswa terjadi peningkatan ada 2 siswa dengan presentase $0.06 \%$ yang mendapat predikat $\mathrm{A} /$ sangat baik, yang mendapat predikat $\mathrm{B} / \mathrm{baik}$ meningkat pada presentase $0.33 \%$, predikat C/cukup sebanyak $0.61 \%$ siswa dan tidak ada lagi siswa yang mendapat predikat D/kurang ,sesuai dengan Interval predikat berdasarkan KKM mata pelajaran Bahasa Inggris kelas XII yaitu 67 seperti nampak dalam tabel 5 berikut ini:

Tabel 5.Interval Predikat Berdasarkan KKM

\begin{tabular}{|c|c|c|c|c|}
\hline Rentang Nilai & Predikat & Kualifikasi & $\begin{array}{c}\text { Jumlah } \\
\text { siswa }\end{array}$ & Persentase \\
\hline $89-100$ & A & Sangat Baik & 2 & $0.06 \%$ \\
\hline $78-88$ & B & Baik & 11 & $0.33 \%$ \\
\hline $67-77$ & C & Cukup & 20 & $0.61 \%$ \\
\hline$<67$ & D & Kurang & 0 & $0 \%$ \\
\hline
\end{tabular}

Sedangkan pencapaian nilai hasil belajar siswa tertinggi adalah 90 dan nilai terendah adalah 68 dengan nilai rata-rata 76. Siswa yang mencapai nilai ketuntasan diatas KKM sebanyak $100 \%$ seperti nampak pada tabel 6 , distribusi nilai hasil belajar siswa pada siklus 2 , berikut ini:

Tabel 3. Distribusi Nilai Hasil Belajar peserta didik Pada Siklus 1

\begin{tabular}{|c|l|c|}
\hline No. & \multicolumn{1}{|c|}{ Uraian } & Hasil Siklus \\
& & $\mathbf{1}$ \\
\hline 1. & Nilai Tertinggi & 90 \\
2. & Nilai Terendah & 68 \\
3. & Nilai rata-rata tes hasil belajar & 76 \\
4. & Jumlah peserta didik yang tuntas belajar & 33 \\
5. & Jumlah peserta didik yang tidak tuntas & 0 \\
6. & Persentase ketuntasan belajar & $100 \%$ \\
\hline
\end{tabular}

\section{Pembahasan}

Secara keseluruhan materi pelajaran pada pokok bahasan tersebut telah memenuhi standar selama tindakan berlangsung dapat dianalisis sebagai berikut. Hasil penelitian siklus I baik dari segi peningkatan motivasi dan hasil belajar Bahasa Inggris kelas XII IPA 4, siswa belum memenuhi target peneliti karena rata - rata motivasi belajar baru mencapai $67 \%$, sedangkan hasil belajar baru 74\% tuntas belajar. Artinya penelitian siklus I belum mampu mewujudkan indikator pencapaian yang ditargetkan yaitu motivasi belajar harus meningkat 
hingga rata-rata 80\%, sedangkan hasil belajar harus meningkat hingga 95\% mencapai nilai diatas KKM yaitu 67. Berdasarkan hasil refleksi pada siklus1, peneliti melakukan beberapa revisi pada rancangan Rencana Pelaksanaan Pembelajaran terutama pada langkah-langkah pembelajarannya. Peneliti juga melakukan pendekatan kepada siswa dalam hal memperkenalkan cara pembelajaran baru menggunakan aplikasi yang biasa siswa gunakan dalam kehidupan sehari-hari di dunia maya.

Hasil penelitian pada siklus II diperoleh hasil: Rata-rata motivasi belajar meningkat hingga $82 \%$, sedangkan hasil belajar siswa $100 \%$ telah mencapai $\geq 67$ dengan menggunakan Instagram dalam proses pembelajaran. Hal ini sesuai dengan penelitian White dkk (2017) yang menunjukkan bahwa penggunaan multimedia digital dapat digunakan untuk meningkatkan hasil belajar kognitif siswa. Artinya hasil penelitian siklus II telah mampu menjawab permasalahan yang diajukan serta telah memenuhi indikator pencapaian yang ditargetkan yaitu rata-rata motivasi belajar siswa meningkat hingga $82 \%$ dan hasil belajar siswa meningkat hingga $100 \%$ mencapai nilai minimal 67.

Dari hasil siklus satu dan siklus dua didapatkan nilai positif bagi siswa dan guru seperti yang diharapkan dalam penelitian ini.

1. Penggunaan media pembelajaran dengan komputer/laptop/gawai menggunakan aplikasi Instagram akan semakin memberikan peluang kepada siswa untuk lebih termotivasi memecahkan masalah, mengembangkan ide gagasan dan mengeksplorasinya dalam dunia maya. Hal ini sesuai dengan yang dinyatakan oleh Nuroifah (2016) bahwa siswa dapat melihat gambar dan video yang telah diunggah sehingga memudahkan siswa dalam memahami materi serta dapat meningkatkan minat belajar siswa

2. Siswa semakin berpengalaman atau terbiasa dalam menggunakan aplikasi Instagram yang berkaitan dengan pembelajaran bahasa inggris yang dioperasikan melalui komputer/laptop/gawai.

3. Siswa lebih termotivasi untuk mencari dan menemukan solusi dari suatu permasalahan dalam kaitannya dengan kehidupan sehari-hari, karena menggunakan aplikasi yang sudah siswa kenal dan sukai dalam keseharian siswa yaitu Instagram.

4. Motivasi belajar dari siswa kelas XII IPA 4 pada pembelajaran Bahasa Inggris materi Caption kelas XII meningkat dengan menggunakan Instagram. Maka penggunaan Instagram sebagai media pembelajaran materi Caption sangat tepat, seperti dinyatakan oleh Mei bahwa penggunaan media visual seperti gambar, animasi dan video dapat digunakan sebagai media pembelajaran yang baik (Mei dkk, 2019)

\section{KESIMPULAN}

Berdasarkan pengamatan pada penelitian tindakan kelas ini, maka dapat disimpulkan bahwa dengan menggunakan media Instagram pada materi Caption mata pelajaran Bahasa Inggris kelas XII IPA 4 dapat meningkatkan motivasi belajar siswa hingga rata-rata $82 \%$. Motivasi belajar siswa juga nampak dalam perolehan nilai hasil belajar siswa. Dengan menggunakan media Instagram pada materi Caption dapat meningkatkan hasil belajar siswa hingga 100\% mencapai ketuntasan belajar dengan KKM Bahasa Inggris 67.

Dari hasil pencapaian tersebut, peneliti percaya bahwa penggunaan Instagram merupakan salah satu cara yang efektif untuk meningkatkan motivasi belajar siswa, khususnya di masa pandemi Covid-19 yang akhirnya harus disikapi dengan Pembelajaran Jarak Jauh secara online (daring). Terlepas dari PJJ secara online (daring), penggunaan media Instagram dalam pembelajaran juga bisa dilakukan tidak hanya secara online (daring), namun juga secara offline( luar jaringan).

\section{DAFTAR PUSTAKA}

Jatmiko, P. (2016). Raising Student Engagement through Instagram. International Conference on Teacher Training and Education. 1.455-460. Surakarta: FKIP UNS. 
Kunandar. (2013). Penilaian Autentik (Penilaian Hasil Belajar Peserta Didik Berdasarkan Kurikulum 2013). Jakarta: Rajawali Press

Mei, X. Y., Aas, E., \& Medgard, M. (2019). Teachers' use of digital learning tool for teaching in higher education: Exploringteaching practice and sharing culture. Journal of AppliedResearch in Higher Education, 11(3), 522-537. https://doi.org/10.1108/JARHE-10- 2018-0202

Nugroho, I. R., \& Ruwanto, B. (2017). Pengembangan Media Pembelajaran Fisika Berbasis. Media Sosial Instagram sebagai Sumber Belajar Mandiri untuk Meningkatkan Motivasi dan Prestasi Belajar Fisika SMA Kelas XI SMA. Jurnal Pendidikan Fisika, 6(6), 460-470.

Nuroifah, N. (2016). Video Media Use The Improvement of Learning Outcomes of The Institute Chemistry Class X SMA Negeri 1 Dawarblandong Mojokerto. Proceedings of International Research Clinic \& Scientific Publication of Educational Technology, 615-633

Purwono, J., Yutmini, S., \& Anitah, S. (2014). Penggunaan Media Audio Visual Pada Mata Pelajaran IPA di SMPN 1 Pacitan. Jurnal Teknologi Pendidikan Dan Pembelajaran, 2(2), 127-144. Retrieved from https://jurnal.fkip.uns.ac.id.

Sardiman. (2018). Interaksi dan Motivasi Belajar Mengajar. Jakarta: Rajawali Pers.

Uno, Hamzah B. (2008). Teori Motivasi dan Pengukurannya Analisis di Bidang Pendidikan. Jakarta: Bumi Aksara.

White, B., Williams, G., England, R., \& Bower, M. (2017). Technology Affordances and Multimedia Learning Effects. Design of Technology-Enhanced Learning, 12, 65-91. 